\title{
RADIOACTIVITY SURVEY ON GODAKAWELA GEM FIELD IN SRI LANKA; TO IDENTIFY THE ORIGIN OF THE UNKNOWN RADIOACTIVE MINERAL
}

\author{
K.A.D.D.N. KURUPPU ${ }^{1}$, H.P.T. SASANKA HEWATHILAKE ${ }^{1 *}$, \\ I.K.M.S.C.K. ILLANGASINGHE ${ }^{2}$, R.A.N.C. RANASINGHE ${ }^{3}$, N. JAYASINGHE ${ }^{2}$ \\ AND T. S. DHARMARATNE ${ }^{2}$ \\ ${ }^{1}$ Department of Science and Technology, Faculty of Applied Sciences, Uva Wellassa University, \\ Badulla, Sri Lanka. \\ ${ }^{2}$ Gem and Jewellery Research and Training Institute, Hidellana, Ratnapura, Sri Lanka. \\ ${ }^{3}$ Sri Lanka Atomic Energy Board, Colombo, Sri Lanka. \\ *Corresponding Author: tharindu.tsh@gmail.com
}

(Received $24^{\text {th }}$ December 2019; accepted $11^{\text {th }}$ February 2020)

\begin{abstract}
Sri Lanka is well known for high-quality gemstones and approximately $25 \%$ of the total land area is liable for potential gem fields. Despite of that identification of new promising gem bearing areas is essential. In Sri Lanka, such investigations are mostly based on the sedimentological and geochemical analysis rather than in-situ radioactive surveys which are common in global contest. Information derived from sporadic studies and gem miners revealed that Godakawela gem field has interesting radioactiveness. Hence, this study focuses on the presence of radioactive minerals, their distribution and the origin of the gem deposit in Godakawela gem field. The ambient gamma dose rate was measured by the plastic scintillation detector from 40 points in random walk mode and gamma energy value was recorded in the NaI scintillation detector. Results have proved that Godakawela region has high radioactiveness with respect to the average baseline value Sri Lanka. The radioactive anomaly pattern and the presence of zircon and tourmaline like associated minerals, together with the surrounded geological aspects have suggested that the radioactive minerals may have a primary origin. Further, X-ray diffractogram shows the corresponding peaks for euxenite as a radioactive mineral but to confirm recrystallization analysis with heat treatment is needed.
\end{abstract}

Keywords: Radioactive Survey, Godakawela gem field, Radioactiveness, Gamma dose

\section{INTRODUCTION}

Sri Lanka has a great reputation for its highquality gems since early historic periods. Approximately $25 \%$ of the total land area of Sri Lanka is liable for potential gem fields (Dissanayake, 1993; Dissanayake and Rupasinghe, 1993). Further, over 75 of precious and semi-precious varieties and sub varieties of gemstones have been identified from Sri Lanka (Gunaratne and Dissanayake, 1995). Dissanayake and Rupasinghe (1995) classified gem deposits in Sri Lanka such as (i). Metamorphic, (ii). Sedimentary and (iii). Magmatic, based on the genesis.

Metamorphic gem deposits are the most common gem deposit type in Sri Lanka since, rocks. The majority of Skarn type gem deposits, such as corundum-bearing deposits, located at Bakamuna near the Elahera area were formed in granulite facies metamorphism (Maesschalck and Oen, 1989). Since the high abundance of aluminous metasedimentary rocks and favorable P-T conditions, most of the aluminous gem varieties can be observed in Highland Complex (HC). Further, the genesis of these gemstones is related to granulite facies metamorphism (Katz, 1986).

Alluvial type gem deposits are mostly containing two or three gem-bearing layers which were occurred as old stream terraces and flood plains. Especially, well-rounded grains with different sizes and varieties are the characteristic features in alluvial gem deposits. Eluvial gem deposits can be found on hillslopes 
and flat areas incised by valleys. Gem gravels which are graded as angular to sub-angular is the characteristic feature in these deposits. The residual gem deposits are mostly in-situ deposits and occur on the flood plains closed to the source. The presence of layers of alternating sand, clays and laterites with angular fragments is the characteristic feature of the residual gem deposits (Dissanayake et al., 2000). Gem deposits under magmatic type are mostly related to the pegmatite origin and are common in the $\mathrm{HC}$. These deposits are containing gem minerals such as beryl, chrysoberyl, zircon, corundum and moonstones (Rupasinghe et al., 1994).

Commonly, Sri Lankan gem deposits are containing gemstone of corundum, chrysoberyl, zircon, tourmaline, garnets, topaz and spinel. However, comparison analysis of gem-bearing sediments and stream sediments have shown that the distribution of heavy minerals and mineral containing Rare Earth Elements (REE) are act as potential indicators for gem deposits (Dissanayake and Chandrajith, 1999; Rupasinghe and Dissanayake, 1984). Further, Dissanayake and Rupasinghe (1992) have explained that rare minerals associated with gem-bearing sediments are rich in REE, Ta, $\mathrm{Nb}$, $\mathrm{Zr}$, Th, U, Ti, Be and F. Nevertheless, both heavy minerals and rare minerals in gem-bearing sediments may contain radioactive minerals such as monazite, zircon, thorianite, thorite and allanite with significant concentrations of $U, T h$, REE and some other trace elements. Rare earth containing minerals are usually dominated by either heavy rare earth elements (HREEs) or light rare earth elements (LREEs). Minerals containing predominantly yttrium and the HREEs include gadolinite, xenotime, samarskite, euxenite, fergusonite. Minerals containing predominantly LREEs include bastnasite, monazite, allanite, lanthanite and cerianite (Al-Ani et al., 2018). Notably, the elemental variation of related gem fields and nearby areas reflects the geology, geochemistry and mineralogy of the source regions. Hence, the investigation of these indicators may be provided the basic idea of the distribution and origin of the unknown gem deposits, specially within the periphery of already identified gem fields (Al-Ani et al., 2018; Dissanayake et al., 2000).

Though, nearly twenty naturally occurring radioactive elements are available, only potassium (K), uranium (U) and thorium (Th) are used as indicators in radioactivity surveys (Johnson, 1979; Gaafar et al., 2016). These elements and/or their isotopes emit gamma rays that can be detected by high-tech instruments such as geiger counters, scintillometers, electrometers, and spectrometers. Measurements of the radioactive properties of naturally occurring elements indicate that a low level of radioactivity is present in almost all rocks and minerals (Hansen et al., 2017). The high intensity peaks recorded by scintillation counters, which detect differences in the intensity of radioactivity, have been widely and effectively used in prospecting for uranium and thorium deposits in recent years (Tennakone, 2011). The use of radioactivity in geology and mineral exploration is based on several properties of gamma radiation such as the penetrating power of gamma rays, the characteristic energy level of the individual elements, and the energy peak used for the detection of the individual element (Johnson, 1979; Wang et al., 2009).

Well documented radioactive mineral occurrences of Sri Lanka include thorianite, urano-thorianite occurrences in Mitipola and Bambarakotuwa (Ratnapura gem field) have been reported by previous studies (Bernard et al., 2014). However, in-situ radioactive survey studies have not been carried out intensively rather than the geochemical and sedimentological analysis. Godakawela area which is situated nearby Rathnapura gem field in Sri Lanka was selected for the present study as a part of a preliminary radioactivity survey due to information derived from gem miners. Gem miners in the particular area have reported an unknown, heavy weight mineral in their gem fields and some sporadic studies have shown that the particular mineral has an interesting radioactivity. Therefore, this study has focused on the identification of the radioactive minerals, their distribution and the origin of the gem deposit in Godakawela gem field.

\section{RATHNAPURA GEM FIELD AND STUDY AREA}

Rathnapura gem field is the most important gem field in Sri Lanka and the gem deposits of this vast field are of alluvial and eluvial types. Charnockites and pelitic, garnet-sillimanite and granulites are the most abundant while the occurrence of intrusive rocks of zircon-bearing granites, vein quartz and pegmatites is of 
particular significance (Herath, 1984; Dissanayake et al., 2000). The Ratnapura gem field consists of Pleistocene or sub-recent alluvium with patches or streaks of gravel of heavy minerals laid down in flood plains of streams, either in the beds of abandoned tributaries at the foot of steep hillslopes (Wadia and Fernando, 1945). The heavy minerals including gems were deposited during periods of intense flooding that caused their mechanical removal from their source areas.

Godakawela gem field is located in a $40 \mathrm{~km}$ distance from Ratnapura. The targeted region is located $6 \mathrm{~km}$ from Godakawela in Masimbula, along the Rakwana road (see Figure 1). It was identified as a small valley adjacent to a quartz deposit in the Masimbula region.

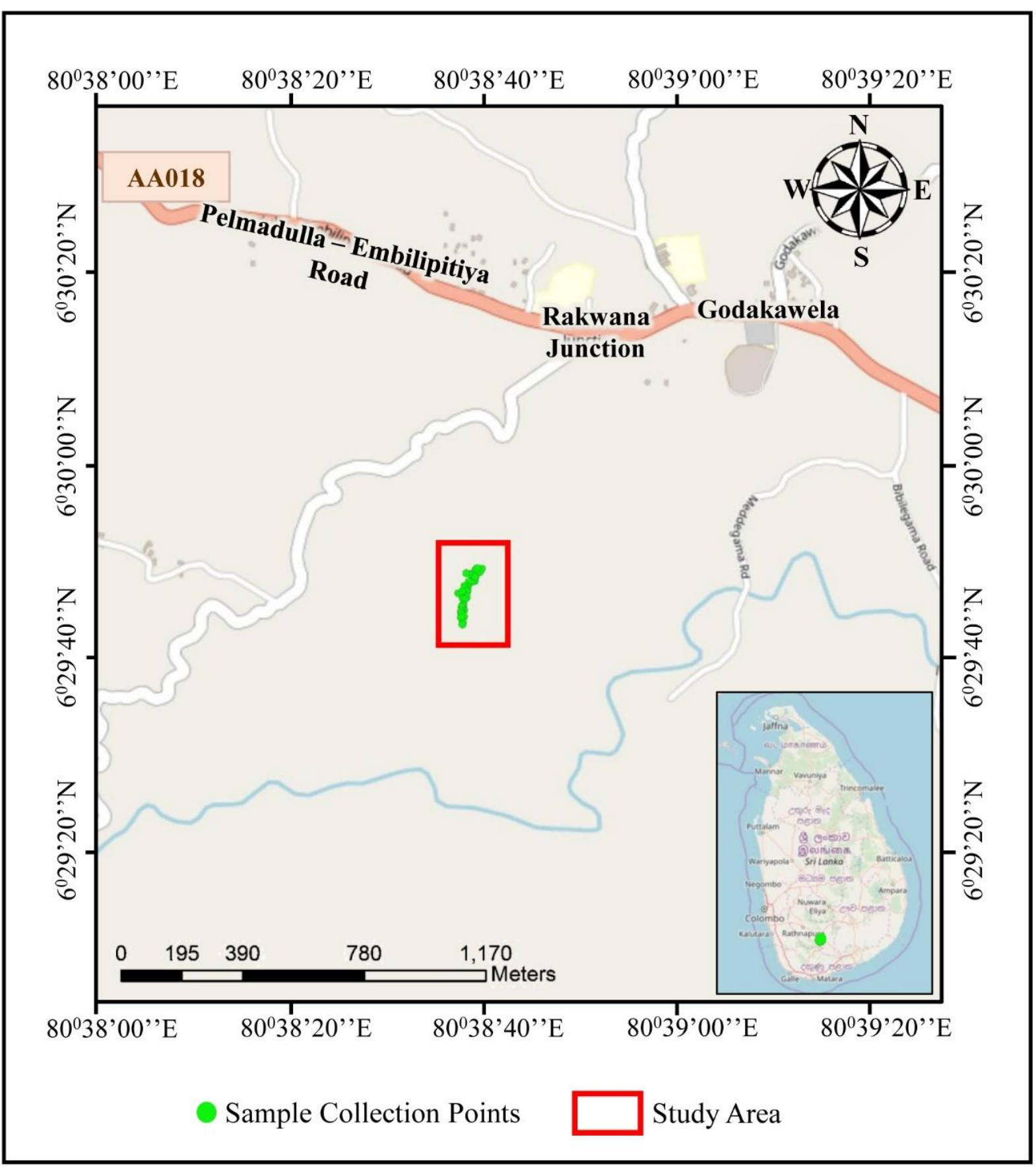

Fig. 1. Location of the Selected Study Area in Godakawela. 


\section{MATERIAL AND EXPERIMENTAL PROCEDURE}

\section{MEASUREMENT \\ OF \\ GROUND}

Plastic Scintillation detector (Saphymo-6150 AD-5/H) and NaI Scintillation detector (Aspect MKC-A03-03) calibrated for ISO/IEC 17025:2005 standards were used to obtain the quantitative and qualitative measurements in the survey. The ambient gamma dose rate was measured by a plastic scintillation detector, whereas gamma energy value was recorded in the NaI scintillation detector. The general radioactivity value in the area was noticed about one feet height from ground and $500 \mathrm{~m}$ away from the selected location. The two instruments were used to obtain data for 40 accessible GPS coordinate points from the bottom of the valley to upwards as well as a flat-lying area of the bottom part of the valley (see Figure 2). The particular GPS coordinates of the sampling points were also obtained by "Garmin" (GPSMAP 78s) in random walk mode.

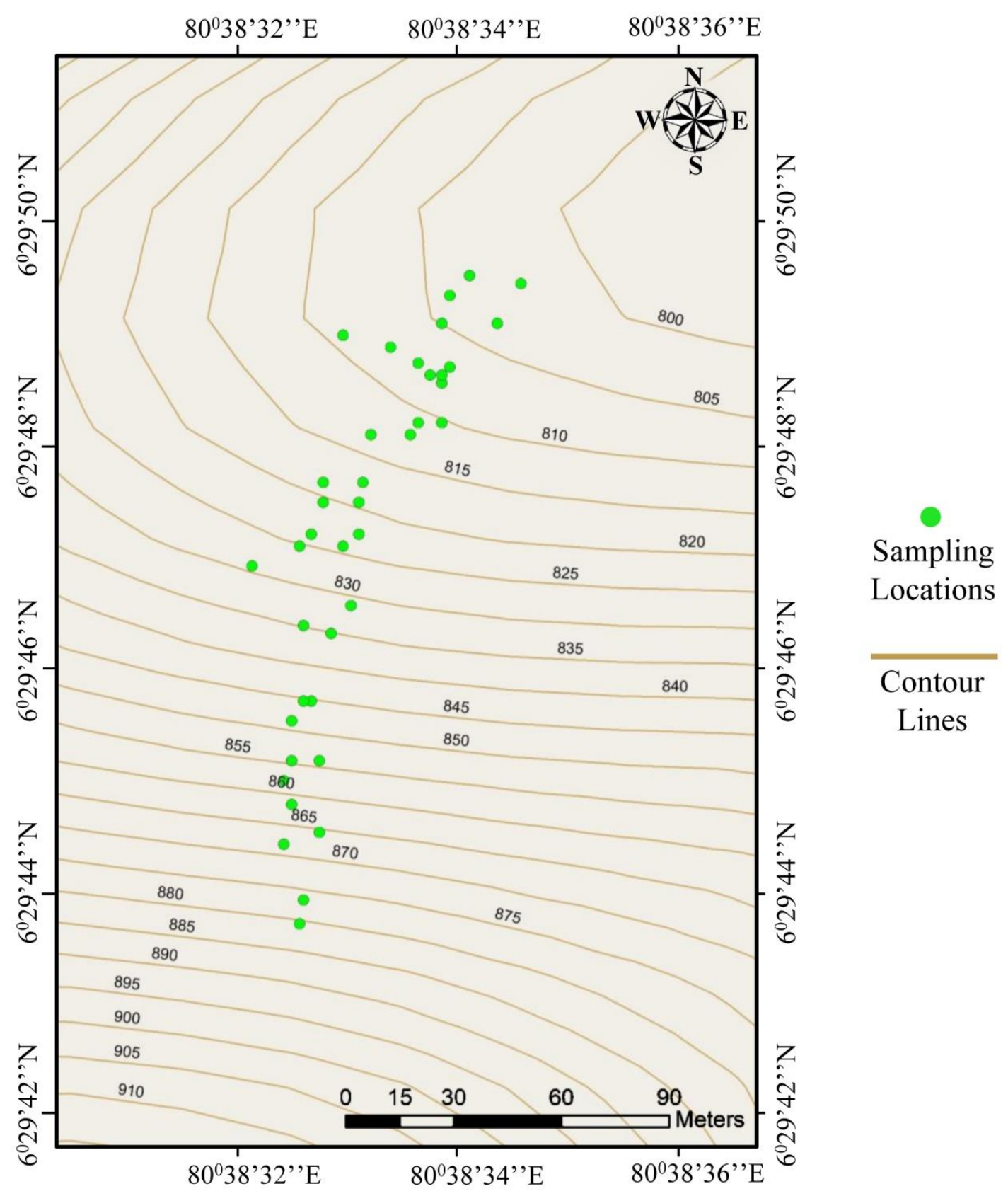

Fig. 2. Morphology and the sampling points of the study area. 


\section{CHARACTERIZATION}

Mineral phase analysis for the radioactive mineral was carried out with X-Ray Diffraction (XRD) analysis on "Rigaku-Ultima IV" X-ray diffractometer, using Ni-filtered $\mathrm{K} \alpha, \mathrm{Cu}-$ radiation $(\lambda=1.54 \AA)$ and $4 \mathrm{deg} / \mathrm{min}$ scanning rate.

\section{RESULTS AND DISCUSSION}

The background radiation level in Sri Lanka varies between $60-320 \mathrm{nSv} \mathrm{h^{-1 }}$ and average gamma dosage value is known to be as $119 \mathrm{nSv}$ $\mathrm{h}^{-1}$ (Seneviratne et al., 2012). The general radioactivity value of the selected area was obtained $500 \mathrm{~m}$ away from the preliminary suspected region and it was recorded as $137 \mathrm{nSv}$ $\mathrm{h}^{-1}$ under the plastic scintillation detector. This value may correspond due to Potassium- $40\left({ }^{40} \mathrm{~K}\right)$ isotope which was observed under the $\mathrm{NaI}$ scintillation detector as a result of its presence in almost all the rocks. Further, ${ }^{40} \mathrm{~K}$ is actively varied widely due to heterogeneous rocks characteristics (Gaafar et al., 2016).

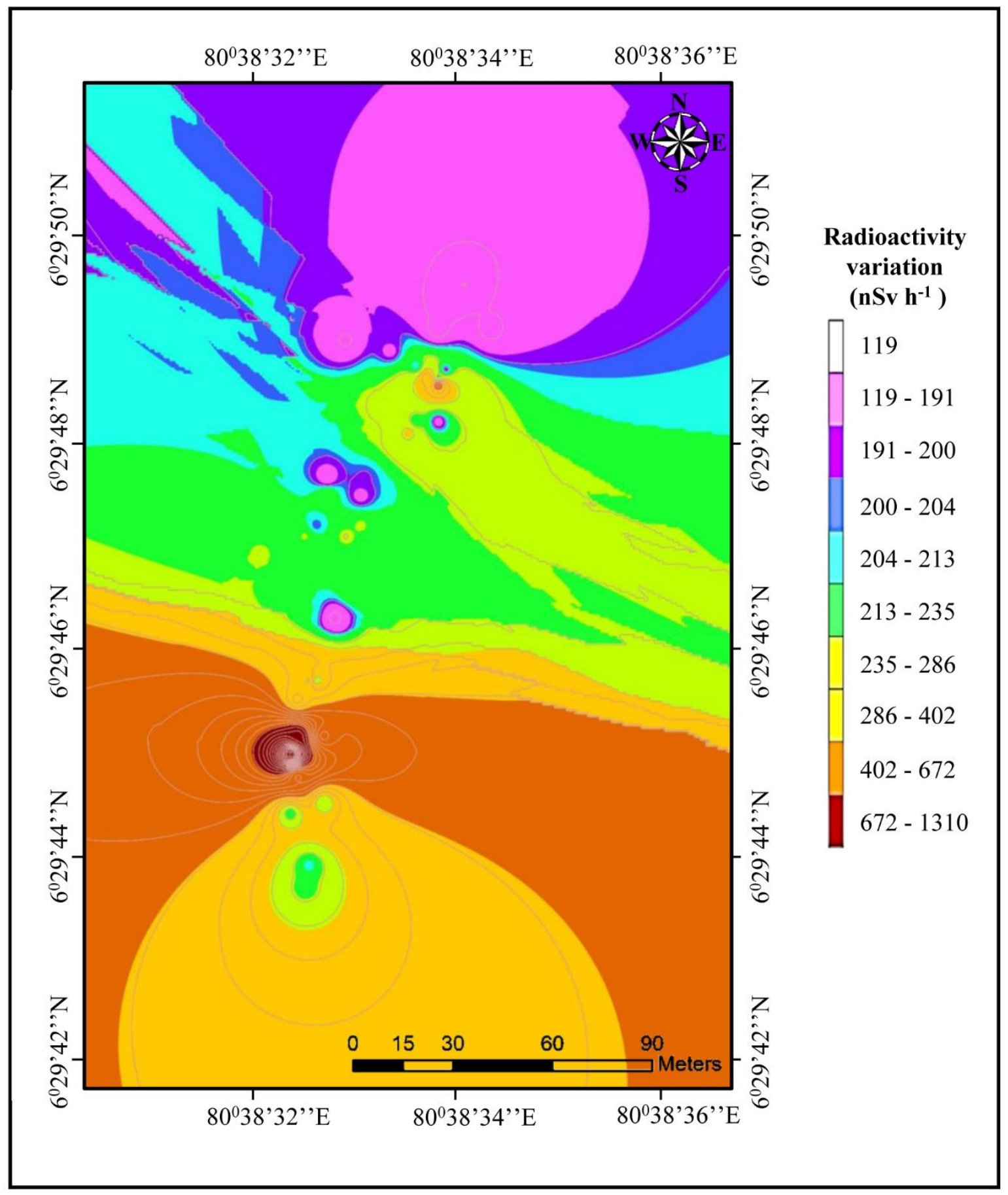

Fig. 3. Radioactive anomaly $\left(n S v h^{-1}\right)$ of the study area. 
When the data was obtained upward along the valley, the gamma dosage tends to increase gradually and has risen to a higher anomaly value which is $1305 \mathrm{nSv} \mathrm{h}^{-1}$ and then retarded down to a normal background value. This depicts that; the radioactive mineral occurrence may concentrate in the middle of valley (see Figure 2 and 3 ) or may have been exposed in the mid region as an underneath layer. Though there is another important anomaly of $476 \mathrm{nSv} \mathrm{h}^{-1}$, in the base of the valley (see Figure 2 and 3), the flat-lying area which bears the paddy field has been normalized to the pre-identified radioactivity value of the area, of average around $180 \mathrm{nSv} \mathrm{h}{ }^{-1}$. This may correspond to a settling of the particular radioactive mineral occurrence along the slope of the valley but due to heavy weight restrictions of the specific mineral, the migration of it be confined to the base of the river basin only. In contrast, a part of the same deposit may have been exposed to the surface from the base of the river basin.

Primary minerals are those originally formed in rocks by solidification from magma or deposition from related solutions, and retain their original form and composition. Secondary minerals are those formed by the alteration of primary minerals (Brown and Fisher, 1962). Hence, there are few supporting factors to

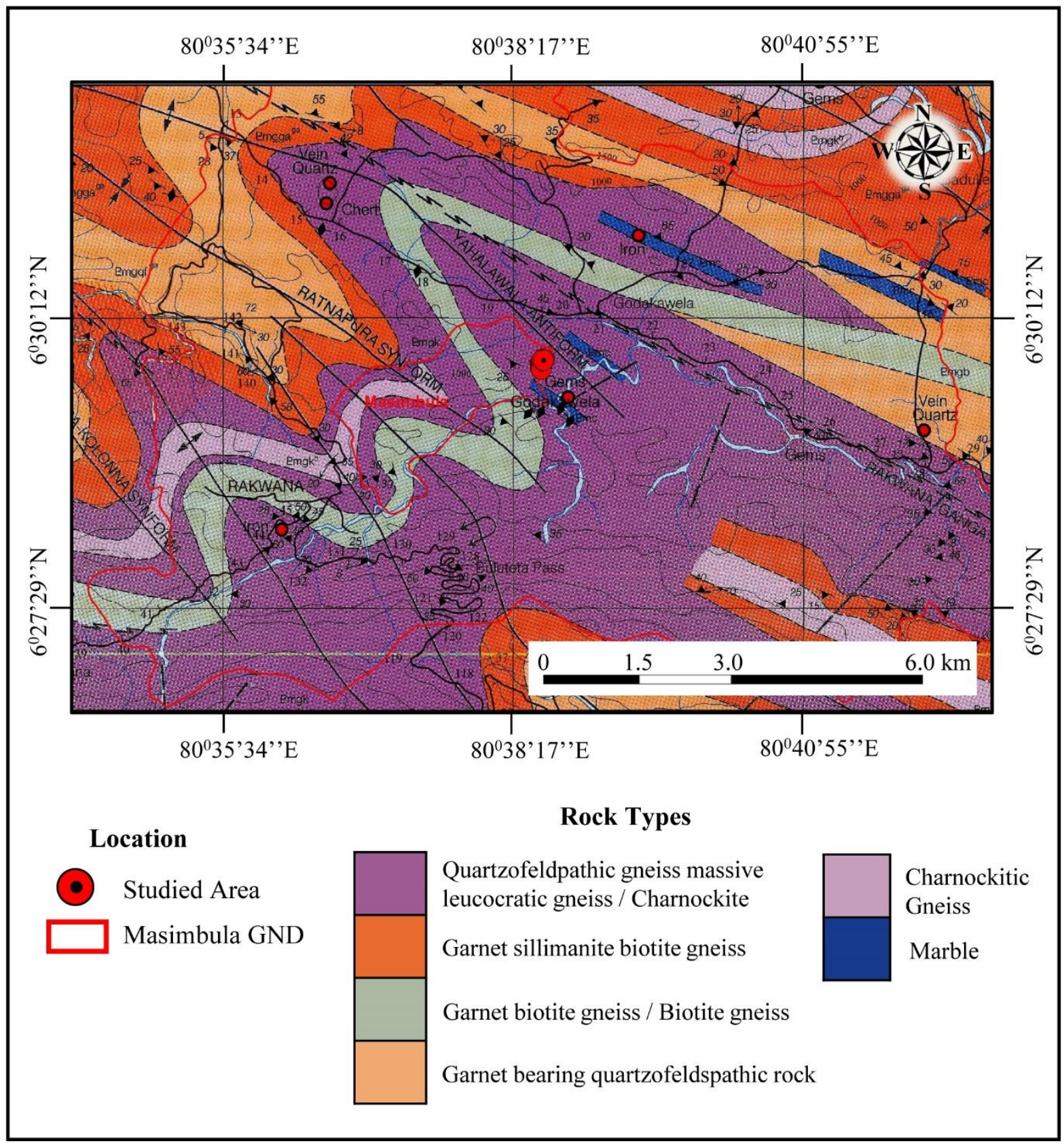

Fig. 4. Geology map of the study area (Source 1:100,000 Geological map series of Sri Lanka. 
assume that this deposit exists far behind a secondary deposit. Because most importantly, the peak anomaly was observed in the mid region of the valley with slope and the base of the valley do not report a high gamma dosage than in mid region. If it is a secondary deposit, a considerable amount of the certain mineral must sediment along the highest altitude of the valley to get settled to the low-lying areas (Figure 2 and 3 ).

However, such variation could not be observed with regard to the gamma dosage values. Even when the geology is considered, a large vein quartz deposit exists in the nearby region. This means that the particular radioactivity mineral deposit is considered to exist in close association with a primary deposit type. This is due to the fact that the vein quartz deposits are of pegmatitic origin where the particular quartz deposit may have been separated from the hydrothermal solution at later stages of crystallization of granitic magmas. Since it is a primary deposit type, associated mineral might also belong to the category of primary deposit type (see Figure 4).

A wide variety of other minerals such as zircon, tourmaline was identified from the same gem bearing field (Figure 5). The presence of a significant amount of fluoride-bearing minerals such as fluorspar (fluorite), apatite, and tourmaline indicate the occurrence of primary pegmatite deposits (Pitawala et al., 2008; Rupasinghe et al., 1984; Dissanayake and Rupasinghe, 1992). Nevertheless, the areas along the Highland-Vijayan boundary are also known to be fluoride-rich (Dissanayake and
Weerasooriya, 1986). Thus, the subjected area in Godakawela along the Highland-Vijayan boundary and obtained evidence of associated minerals together with quartz deposit nearby, confirm that there might be a large primary pegmatite deposit which should be clarified with further radioactivity survey. Furthermore, this confirms the primary origin of the identified radioactive mineral occurrence. Further to that radioactive mineral samples with metamict nature were observed (Garver, 2002) and hence, a specific crystal structure could not be detected (Figure 5). However, associated minerals such as tourmaline and zircon were occurred as wellformed crystals (Figure 5) predicting the primary origin (Brown and Fisher, 1962).

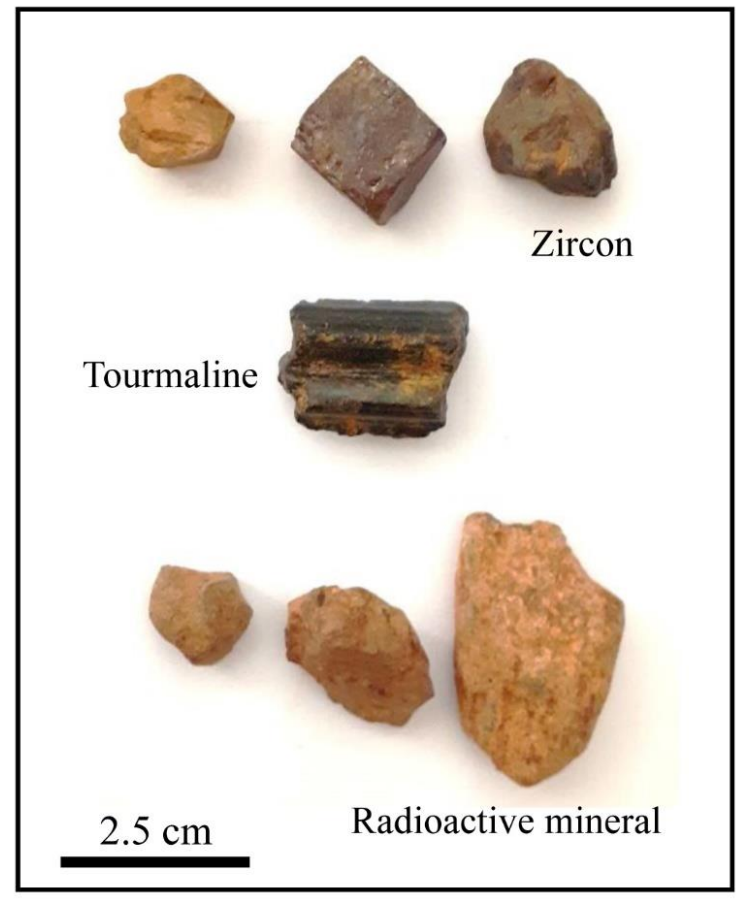

Fig. 5. Associate minerals and radioactive mineral found in the area.

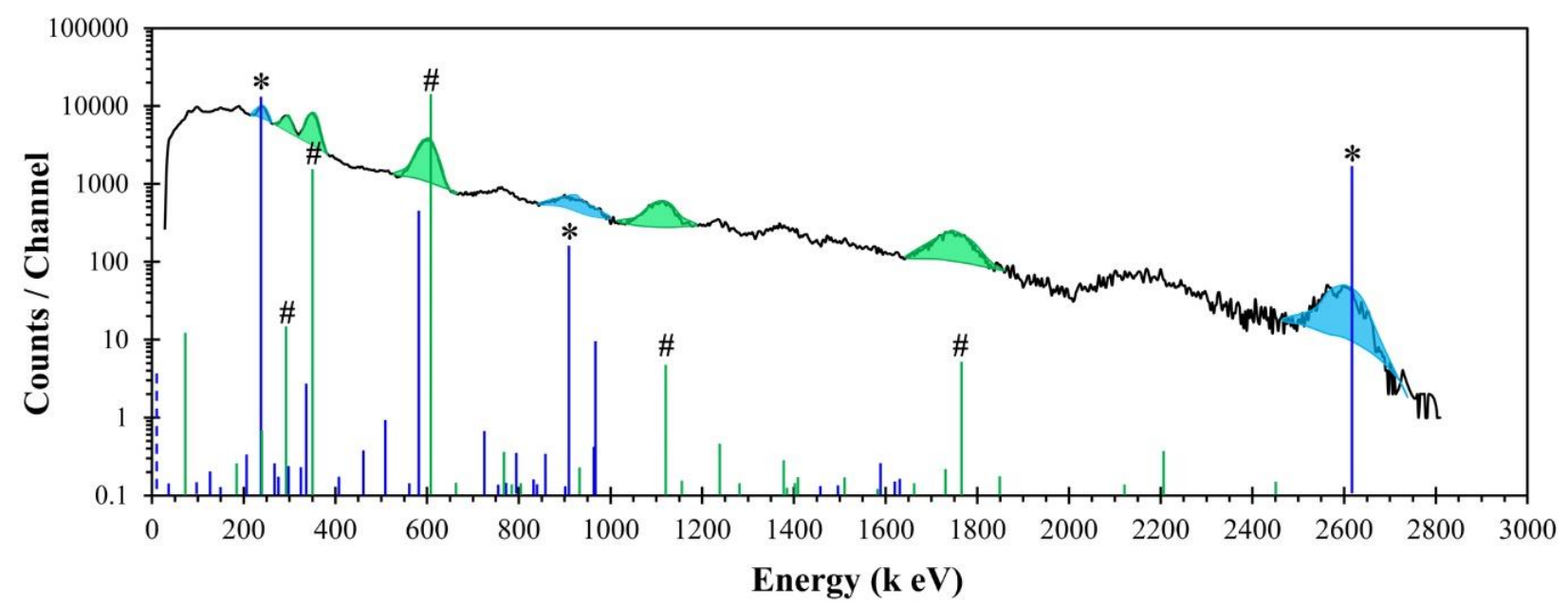

Fig. 6. Radioactivity of unknown radioactive mineral found in the study area. * and \# symbols denote the Radium (Ra) and Thorium (Th) peaks in the sample, respectively. 
The radioactive mineral samples with metamict nature were separately analyzed with the $\mathrm{NaI}$ scintillation detector. The obtained results express that the majority of the peaks or the energy lines related to certain high anomaly regions are due to the Thorium (Th) and Radium (Ra) elements (Figure 6).

Figure 7 explains the mineral phase identification carried out by XRD analysis. Three broad peaks have been detected which explained the partially crystalline nature of the metamict radioactive mineral sample. However, two peaks which are in $30^{\circ}$ and $51.55^{\circ}$ of two theta $\left(2 \theta^{\circ}\right)$ values are corresponded to the 311 and 620 phase of euxenite mineral, respectively (Tomašić et al., 2008).

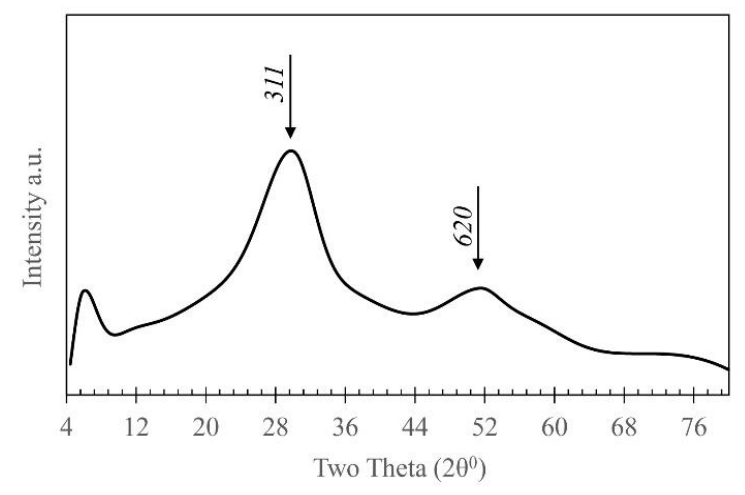

Fig. 7. X-ray diffractogram of the metamict radioactive mineral sample.

However, to confirm the metamict radioactive mineral as euxenite, XRD analysis should be conducted with the recrystallization, induced with heat treatment and annealing.

\section{CONCLUSIONS}

The selected area in the Godakawela region shows significantly high radio activeness with respect to the average baseline radioactivity value in Sri Lanka. The anomaly pattern of this primary radioactive survey evidences that there is a high tendency to categorize this occurrence as a primary origin. X-ray diffraction analysis has suggested that the metamict radioactive mineral may be euxenite. However, further analysis should be carried out with recrystallization by heat treatment and annealing. Nevertheless, a systematic and detailed radioactivity survey and a core sample analysis are suggested to clarify the origin and distribution of this deposit.

\section{REFERENCES}

Al-Ani, T., Molnár, F., Lintinen, P. and Leinonen, S. (2018) Geology and Mineralogy of Rare Earth Elements Deposits and Occurrences in Finland. Minerals, 8(8): 356.

Bernard, N.P., Edirisinghe, G.D.N., Silva, K.T.U.S.D. and Dissanayake, D.M.S. (2014) Samarskite-Polycrase Group Minerals and Other Radio-Active Minerals Associated with Gem Gravels in the Ratnapura Gem Field of Sri Lanka. In Proc. $30^{\text {th }}$ Technical Session: Geological Society of Sri Lanka.

Brown, R.E. and Fisher, R.V. (1962) The Ore bin; Vol. 24 No. 12 (December 1962).

De Maesschalck, A.A. and Oen, I.S. (1989) Fluid and mineral inclusions in corundum from gem gravels in Sri Lanka. Mineralogical Magazine, 53(373): 539-545.

Dissanayake, C.B. and Weerasooriya, S.V.R. (1986) Fluorine as an indicator of mineralizationHydrogeochemistry of a Precambrian mineralized belt in Sri Lanka. Chemical Geology, 56(3-4): 257-270.

Dissanayake, C.B. and Rupasinghe, M.S. (1992) Application of geochemistry to exploration for gem deposits, Sri Lanka. J. Gemm, 23(3): 165175.

Dissanayake, C.B. and Rupasinghe, M.S. (1993) New gem localities in Sri Lanka.

Dissanayake, C.B. (1993) A prospectors 'guide map to the gem. Gems \& Gemology, 29(3): 173-181.

Dissanayake, C.B. and Rupasinghe, M.S. (1995) Classification of gem deposits of Sri Lanka. Geologie en Mijnbouw, 74: 79-79.

Dissanayake, C.B. and Chandrajith, R. (1999) Sri Lanka-Madagascar Gondwana linkage: evidence for a Pan-African mineral belt. The Journal of Geology, 107(2): 223-235.

Dissanayake, C.B., Chandrajith, R. and Tobschall, H.J. (2000) The geology, mineralogy and rare element geochemistry of the gem deposits of Sri Lanka. Bulletin-Geological Society of Finland, 72(1/2): 5-20.

Gaafar, I., El-Shershaby, A., Zeidan, I. and El-Ahll, L.S. (2016) Natural radioactivity and radiation hazard assessment of phosphate mining, QuseirSafaga area, Central Eastern Desert, Egypt. NRIAG Journal of Astronomy and Geophysics, 5(1): 160-172.

Garver, J.I. (2002) Discussion:"Metamictisation of natural zircon: accumulation versus thermal annealing of radioactivity-induced damage" by Nasdala et al. 2001 (Contributions to Mineralogy and Petrology) 141: 125-144. Contributions to Mineralogy and Petrology, 143(6): 756-757.

Gunaratne, H.S. and Dissanayake, C.B. (1995) Gems and gem deposits of Sri Lanka. National Gem and Jewellery Authority of Sri Lanka. 
Hansen, V., Søndergaard, J., Asmund, G., Aastrup, P., Gustavson, K., Garcia, G., Nymand, J. and Larsen, M.B. (2017) Exploitation of radioactive minerals in Greenland: Management of environmental issues based on experience from uranium producing countries. Aarhus University, DCE-Danish Centre for Environment and Energy.

Herath, J.W. (1984) Geology and occurrence of gems in Sri Lanka. The Journal of the National Science Council of Sri Lanka, 12(2): 257-271.

Katz, M.B. (1986) Review of the geology of the gemstones of Sri Lanka. The Australian Gemmologist, 20: 52-61.

Pitawala, A., Amaraweera, T.H.N.G. and Fernando, G.W.A.R. (2008) Pegmatites derived from fractionations of a primitive melt; an example from pegmatites in the Owala-Kaikawala area, Matale, Sri Lanka. J. Geol. Soc. India, 72(6): 815822.

Rupasinghe, M.S. and Dissanayake, C.B. (1984) The rare-earth element abundance in the sedimentary gem deposits of Sri Lanka. Lithos, 17: 329-342.

Rupasinghe, M.S., Banerjee, A., Pense, J. and Dissanayke, C.B. (1984) The geochemistry of beryllium and fluorine in the gem fields of Sri Lanka. Mineralium Deposita, 19(1): 86-93.

Rupasinghe, M.S., Dissanayake, C.B. and Mendis, D.P.J. (1994) Use of indicator minerals in gem exploration: study of a granulitic terrain in Sri Lanka. Journal of Southeast Asian Earth Sciences, 9(3): 249-254.

Seneviratne, M.C.S., Mahakumara, P.D., Attanayaka, T.N., Sanjeewani, S., Edirisinghe, V., Kumara, K.S.S., Kadadunna, K.K.P.L.K., Edirisinghe, J., Perera, G., Handagiripathira. H.M.N.L. and Waduge, V.A. (2012) Baseline Radioactivity of soil in Sri Lanka. In Proc. $68^{\text {th }}$ Annual Session of Sri Lankan Association for the Advancement of Science.

Tennakone, K. (2011) Thorium minerals in Sri Lanka, history of radioactivity and thorium as a future energy source: a compendium to commemorate the International Year of Chemistry 2011. Journal of the National Science Foundation of Sri Lanka, 39(2): 97-111.

Tomašić, N., Bermanec, V., Gajović, A. and Rajić Linarić, M. (2008) Metamict minerals: an insight into a relic crystal structure using XRD, Raman spectroscopy, SAED and HRTEM. Croatica Chemica Acta, 81(2): 391-400.

Wadia, D.N. and Fernando, L.J.D. (1945) Gems and semi-precious stones of Ceylon. Ceylon Department of Mineralogy, Professional Paper, 2: 13-44.

Wang, P., Fang, F., Wang, X., Zhao, X. and Li, L. (2009) Study of gamma spectrometry and radioactive prospecting. Taking example for Maoming oil shale mine of Guangdong. Uranium Mining and Metallurgy, 28(3): 151-154.

Weitzel, H. (1980) Kristallstrukturverfeinerungen von Euxenit, $\mathrm{Y}\left(\mathrm{Nb}_{0.5} \mathrm{Ti}_{0.5}\right)_{2} \mathrm{O}_{6}$ und M-Fergusonit,
$\mathrm{YNbO}_{4}$. Zeitschrift für KristallographieCrystalline Materials, 152(1-4): 69-82. 
